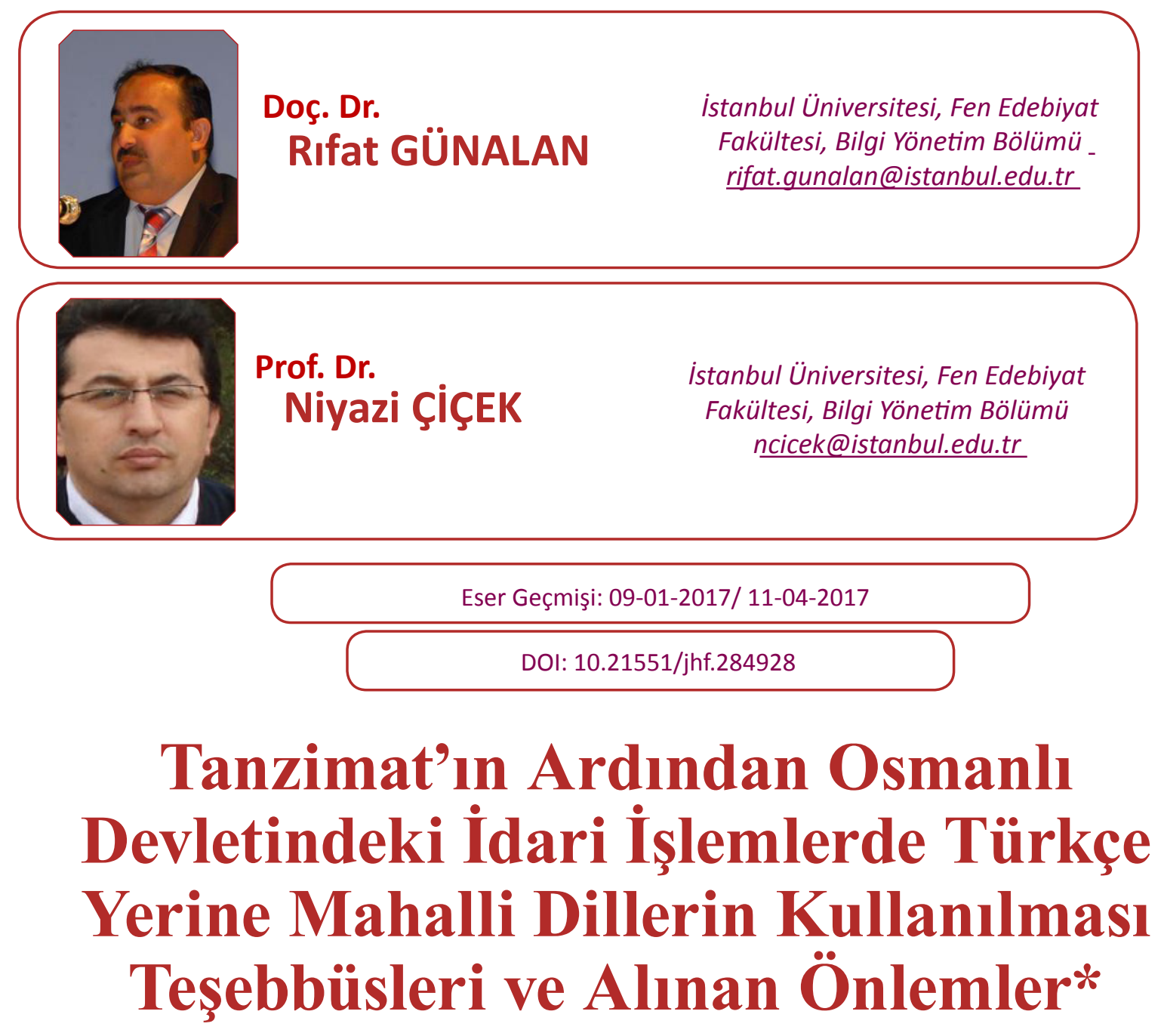

\title{
Attempts to Use of Local Communities Instead of Turkish in the Administrative Transactions of the Ottoman State after the Tanzimat, and Taken Measures
}

\section{ÖZET}

Osmanlı Devletinde 1839 yılında yayınlanan Tanzimat Fermanının ardından gelen yenileşme hareketleri ve bir takım imtiyazlarla birlikte, birçok alanda olduğu gibi idari işlemlerde de yeni uygulamalar söz konusu olmuştur. Bir sözleşmeden, sıradan bir arzuhal veya istidaya kadar birçok belgede, Türkçe'nin yanı sıra yabancı dillerin de kullanılması talepleri gündeme gelmiştir. Bunların bir kısmı Rumca, Arapça şeklinde mahalli dillerken, bazıları İngilizce, Fransızca gibi yabancı dillerdir. Gerek kamu idaresindeki işlemlerde, gerekse şirketlerin işleri ve halkın taleplerinde kullanılan yazışma ve belgelerde bu diller kullanılmıştır. 0 döneme ait belgeler arasında Rumca arzlara, Fransızca sözleşmelere rastlamaktayız. Konuyla ilgili karşılaşılan arşiv belgelerinde bu tür uygulamaların geleneksel yazışma usulü ile idari işlemleri olumsuz yönde etkilediği görülmüştür. Bu durum Osmanlı bürokrasisinde "farklı dillerde üretilen belgeler, idari işlemlerde problemlere sebep olmaktadır kanaatini oluşturmuştur". İdari işlemlerdeki dil problemine birkaç şekilde rastlıyoruz. Bunlardan öne çıkanlardan ilki, belgelerin tamamen yabancı bir dilde üretilmesi; ikincisi ise Türkçe yazışmaların içerisinde çok yaygın olarak bilinmeyen yabancı 
kökenli kelimelerin kullanılmasıdır. Bu çalışmada bürokraside farklı dillerin kullanılmasıyla ortaya çıkan sorunlar tartışılmış, konu bürokrasi dili ile sınırlandırılmış, azınlıkların veya yabancıların kendi dillerini eğitim, kültür veya yayın hayatında kullanmaları konularına girilmemiştir. Etkiler incelenirken, idarenin de buna karşı aldığı önlemler değerlendirilmiştir. Sonuçta bu farklı dilleri kullanmak yerine, devletin yazışma dilinde tamamen Türkçe'ye döndügünü görmekteyiz. Konu ele alınırken, ilk elden arşiv belgeleri incelenmiş ve örneklerle zenginleştirilerek farklı uygulamalara dikkat çekilmiştir.

Anahtar Kelimeler: Osmanlı Tarihi, Tanzimat, Osmanlı Büroksasisi, Arşiv

\section{ABTRACT}

In the Ottoman Empire, the Tanzimat Ferman which was published in 1839 and the new movements and some privileges, as well as the new practices in the administrative processes, such as many arena. There has been a demand for the use of foreign languages as well as Turkic, as well as a lot of documents from a convention, to an ordinary supply or to the occasion. Some of them are in the local language in the form of Greek, Arabic, some of them are foreign languages like English and French. These languages have been used in correspondence and documents used in the public administration, in the works of the companies and in the demands of the people. Among the documents belonging to that turn, we find French contracts in Greek supplies. In archival documents related to this issue, it has been seen that such applications affected the traditional corresponden ce procedure and administrative procedures n e gatively. According to the Ottoman bureauc $\mathrm{r}$ acy, this was the opinion that "documents produced in different languages are causing problems in administrative procedures". We encounter several problems with the language problem in administrative proceedings. One of the most prominent of these is the fact that documents are produced on a completely foreign language; And the second is the use of words of foreign origin which are not widely known in Turkish correspondence. In this study, the problems arising from the use of different languages in the bureaucracy are discussed, the issue is limited to bureaucratic language, and minorities and strangers are not allowed to use their languages in education, culture or publication. When the impacts were examined, the measures taken by the victim were evaluated. In the end, instead of using these different languages, we see that the state has become completely Turkish in the language of correspondence. While discussing the subject, archival documents from the first hand were examined and enriched with examples and different applications were noted.

Keywords: Ottoman History, Tanzimat, Osmanlı Büroksasisi, Archives 
$\mathrm{T}$ arih boyunca Türklerin kurduğu devletlerde çeşitli ülke ve milletlerle olan münasebetler sırasında Türkçenin dışında farklı diller kullanılmıştır. Özellikle Selçuklular ve Osmanlılarda bu uygulama sıkça rastlanan bir durumdur. İlk başlarda Farsça ve Arapça, medreselerde eğitim ve edebiyat dili olarak kendine yer edinirken, bahsi geçen diller aynı zamanda bürokrasideki idari işlemlerde de kullanılmıştır.

$\mathrm{Bu}$ uygulamalar sırasında doğu dilleri yanı sıra batı dillerine de rastlanmaktadır. Anadolu Selçukluları zamanında I. İzzeddin Keykâvus ile Kıbrıs Kralı Hugues arasında Yunanca yazışmalar ve ahidnâmeler olduğu, yine Alâaddin Keykubat'ın Venediklilerle Lâtin dilinde ticari antlaşmalar yaptığı bilinmektedir ${ }^{1}$. Osmanlı Devlet geleneğinde de gerektiğinde farklı dillerin kullanıldığını hem arşiv belgelerinden hem de yapılan yayınlardan anlıyoruz. Tanzimat'tan önce de Türkçenin dışındaki dillerde yazışmalar yapılmıştır. Osmanlı bürokrasisinde kullanılan diller ve tercümanlar üzerine çalışmaları bulunan Bilgin Aydın, Osmanlı Devleti'nin kuruluşundan itibaren devlet işlerinde Türkçenin dışında diğer dillerin de kullanıldığına işaret etmektedir ${ }^{2}$. Bernard Lewis'in belirttiğine göre Yunanca ve Slâv diline hâkim bir padişah olarak Fatih Sultan Mehmet, Yunanca ferman dahi çıkarmıștır³. Avrupa'da hem resmi ve diplomatik dilde hem de hukuk dilinde yaygın olarak kullanılan Latince, Osmanlı'nın diplomatik münasebetlerinde -özellikle karşılıklı müzakere ve anlaşmalardakendine yer edinmiştir. 1699'da imzalanan Karlofça Antlaşması, 1718'de imzalanan Pasarofça Antlaşmaları Latince ve Türkçe olarak kaleme alınmıştır4. 18. yy.dan sonra Osmanlı'nın uluslararası ilişkilerindeki müzakerelerinde Latincenin yerini İtalyanca almıştır. 1774 yılında imzalanan Küçük Kaynarca Antlaşması örnek olarak gösterilmektedir55.

Bazı araştırmacılara göre Fransızcanın Türk toplumuna girişi ve yaygınlık kazanmasının başlangıcl, 17. yy.'dan itibaren Osmanlı askeri okullarında çalışmaya başlayan batılı uzmanların Fransızca kullanmalarıyla bașlatılabilir6. Sonraki yıllarda eğitim bașta olmak üzere, ticari faaliyetler ve bürokraside Türkçenin dışında Fransızca yaygın bir dil haline gelmişti. Dış münasebetlerde tercümanlar vasıtasıyla farklı diller yanında özellikle Fransızca

* Bu makale, Uluslararası 22. CIEPO Sempozyumunda (Trabzon 4-8 Ekim 2016) sunulan “Tanzimat'ın Osmanlı Yazışma Geleneğine Etkisi Işığında Bürokraside Yaşanan Dil Problemleri: İdari İşlemlerde Türkçe'nin Yerine Mahalli Dillerin Kullanılması" başlıklı tebliğin, eklemler yapılarak yeniden düzenlenmiş halidir. Ayrıca İstanbul Üniversitesi Bilimsel Araştırma Projeleri Koordinasyon Birimi (BEK)'in 22374 kodlu projemize destekleriyle hazırlanmıştır.

1 .. Melek Delilbaşı. Türk Hükümdarlarına Ait Yunanca Ahidnameler ve Nameler (XIII-XV. Yüzyıl), Ankara Üniversitesi DTÇF Ortaçağ Tarihi Kürsüsü, 1980 (Yayınlanmamış Doçentlik Tezi), s. 11-40.

2 Bilgin Aydın, “Osmanlı Bürokrasisinde Doğu-Batı Dilleri ve Türkçe”, Essays in Memory of Hazel E. Heughan, Ed. İsmail E. Erünsal, Chistopher Ferrard, Hamza Kandur, A. Oğuz İcimsoy, Niyazi Çiçek, Edinburg: Hazel E. Heughan Educational Trust Publication, 2007. s. 49-58.

3 Bernard H. Lewis, Müslümanların Avrupa'yı Keşfi, Çev. Dr. Nimet Yıldırım, Erzurum: Birey, 1997, s. 112.

4 Lewis, a.g.e, s. 112.

5 Davison, Roderic H. “Ondoküzuncu Yüzyıl Osmanlı Reformlarına Araç Olarak Fransız Dili”, Çev. Çiğdem Erkal İpek, İzmir, Dokuz Eylül Üniversitesi Atatürk İlkeleri ve İnkılap Tarihi Enstitüsü Çağdaş Türkiye Tarihi Araştırmaları Dergisi, c. 2, s. 4-5, 1995, s. 171.

6 Sezai Balc1, “Osmanlı Devleti'nde Modernleşme Girişimlerine Bir Örnek: Lisan Mektebi”, Ankara Üniversitesi Dil ve Tarih-Coğrafya Fakültesi Tarih Bölümü Tarih Araştırmaları Dergisi, c.27, s.44, 2008, s.7778. 
yoğun şekilde kullanılmıştır. 19. yüzyılda ve 20. yüzyılın başında Osmanlı topraklarında çok sayıda gazete Fransızca yayınlanıyordu. Sokak tabelaları Fransızca ve Türkçeydi. Dış ilişkiler gibi belirli alanlarda resmi yazışmalar Fransızca ve Türkçe yazılıyordu 1920 yılında bile PTT'de çalışanlar sadece Fransızca konuşuyordu. PTT'deki bilgi broşürleri ve yıllıklar bile sadece Fransızca olarak yazılmıştır ${ }^{8}$. Tanzimat döneminden beri Osmanlı Hariciye Nezaretinin yazışma dili Fransızca idi. Bakanlık ile Osmanlı dış temsilcilikleri arasında yazışmalar Fransızca olarak kaleme alınıyordu. Ali Akyıldız’ın bildirdiğine göre 1853 yılında yapılan düzenlemeye kadar Osmanlı Devleti yabancı devletlerde bulunan sefirleriyle yazışmalarını Fransızca yapmaktaydı. Fakat, bu yazıların tercüme edilerek kullanıldığını ${ }^{9}$, bunun da zaman kaybına sebep olduğu ileri sürülerek, sefaretlerle hükümet arasındaki yazışmaların bundan sonra mümkün mertebe Türkçe yazılması hususu dile getirilmiştir. Hariciye Nezaretinin yurt dışındaki elçiliklerle yaptığı yazışmalar genellikle Fransızca yürütülürken, 18.yy.'ın ikinci yarısından itibaren bu dilin Devletin farklı idari işlemler ve ticari anlaşmalarında kullanılmaya başladığı görülmektedir. 0 dönemin hem yenileşme hareketlerinin doğurduğu sonuçlara ve hem de azınlıklara verilen imtiyazlara bakıldığında Fransızcanın yabancı dil olarak yaygınlık kazanmış olduğu çok açıktır

Tüm bunlardan dolayı hem devlet ișlerinde hem de dıșarıyla olan münasebetlerde zaman zaman başta doğu, daha sonraları da batı dillerinde yazılmış belgelere rastlanmaktadır. Bürokraside Türkçe'nin dışında farklı dillerin kullanılması birkaç nedene bağlanabilir. Savaş ve ticaret gibi sebeplerle Osmanlı'nın farklı devletlerle olan diplomatik münasebetleri, Osmanlı toplumunun farklı milletlerden oluşmasından dolayı çok kültürlü bir yapıya sahip bulunması, Tanzimat gibi yeni düzenlemelerin getirdiği imtiyazlar, özellikle dış ilişkilerde yabancı elçilerin tesiri, yine İmparatorluğun son dönemlerinde Avrupa'ya gönderilen elçi ve bürokrat ile daha sonraki dönemlerde giden öğrencilerin Fransızca başta olmak üzere farklı dilleri de kullanmaları ilk dikkat çeken sebeplerdir.

Devlet içerisinde kullanılan yabancı diller yanında yerel diller de bulunuyordu. Osmanlı Devleti sınırları içerisinde çok farklı topluluk ve kültürlerin bulunması tabii olarak Türkçe'den başka dillerin de konuşulmasına sebep oluyordu. Bunlar, Rum, Yahudi, Ermeni, Süryani ve Bulgar gibi azınlıklar ile Fransız, İngiliz ve Araplara ait dillerdi. Farklı toplulukların bu dilleri, o toplumun fertleri arasında konuşulurken aynı zamanda o kültüre ait yazılı literatür de yine kendi dillerinde gelişmekteydi. Bunun en belirgin örneğini eğitim ve yayın hayatında görüyoruz. Çünkü bu toplulukların edebî faaliyetlerinin yanı sıra kendi okullarındaki eğitim de yerel dillerle yapılıyordu. Doğal olarak bu farklı topluluklara ait yazılı kültürün kendi yerel dillerinde geliştiği söylenebilir.

Her ne kadar çok milletli ve kültürlü toplumsal yapı, Osmanlı toprakları içerisinde yerel ve yabancı dillerin konuşulması sonucunu doğursa da bir takım imtiyaz ve özgürlük

7 Hüseyin Gümüş, "Fransızca ve Francophonı: Niçin, Ne Zaman, Nerede, Nasıl ?", Türkish Studies International Periodical For the Languages Literature and History of Turkish or Turkic, vol. 8/10 Fall 2013, s. 308.

8 Hüseyin Gümüş, a.g.m, s. 308.

9 Başbakanlık Osmanlı Arşivi Hariciye Mektûbî Kalemi, (BOA. HR. MKT). 58/99; Ali Akyıldız, "Tanzimat Döneminde Belgelerin Şekil, Dil ve Muhteva Yönünden Geçirdiği Bazı Değişiklikler (1839-1856)", Tanzimat: Değişim Sürecinde Osmanlı Imparatorluğu, Haz. Halil İnalcık, Mehmet Seyitdanlığlu, İstanbul: Türkiye İş Bankas1, 2006, s. 410. 
ortamlarının da bu dillerin daha fazla kullanılmasında etken olduğu görülmektedir. Özellikle Tanzimat Fermanı, Islahat Fermanı ve Meşrutiyetin ilanı başlıca etkenlerdendir ${ }^{10}$. Tanzimat'ın ardından oluşan özgürlük ortamı, azınlıkların bir takım hak ve imtiyazlar elde etmelerine imkân vermiștir. Bunlardan biri de bürokratik işlemlerde kendi yerel dillerini kullanabilme kolaylığıdır. Kendi milli, dini ve kültür unsurlarını daha rahat yaşama ve kullanma fırsatının doğmasının ardından, Devletle yürütülen işleri yerel dilleriyle yapma talepleri daha güçlü dile getirilmiştir. Bu taleplerin doğal sonucu olarak kendi dillerinde belge hazırlayıp bununla Devlete müracaat ederek işlem yaptırma süreci başlamıştır. İlber Ortaylı'nın aktardığına göre Balkan bölgesinde Slav kökenli topluluklar Bulgarca, Sırpça, Hırvatça dilekçelerle işlem yaptırmak istemişlerdir. Özellikle 1856 Islahat Fermanından sonra kilise ve benzeri dini ve kültürel mekânların yapım, tamir ve genişletilmesine dair Bâb-ı âliye verilen dilekçeler kendi dillerindedir ${ }^{11}$.

Devlette günlük muamelat yaygın olarak Türkçe yapılmasına rağmen Hırvatça dilekçe örneğinde olduğu gibi zaman zaman farklı dillerde yazılmıș belgelere rastlanmaktadır ${ }^{12}$. Bir takım uygulamalardan idarecilerin Türkçeyi kullanmak noktasında aslında ısrarcı oldukları ve gerektiğinde bu durumun memurlara hatırlatıldığı, hatta yabancı dilde kelimeler yerine ısrarla Türkçelerinin tercih edilmesi gerektiğinin vurgulandığı; bu konuda hassasiyet göstermeyen memurların da uyarıldığını ve zorunlu hallerde sürgün edildiği bilinmektedir ${ }^{13}$. Buna rağmen özellikle ülkedeki reform dönemlerinin yabancı dillerin kullanılması için uygun zemin oluşturduğu görülmektedir.

\section{Bürokraside Yaşanan Dil Problemleri}

\section{Yazışmalarda Anlam Karmaşası}

Osmanlı bürokrasisindeki yazışmalarda Türkçenin dışında kullanılan dil ve kavramlar, bazen tam anlaşılamadığından bazen de kelimelere farklı anlamlar yüklendiği için zaman zaman problemler yaşanmasına sebep olmaktaydı. İdari işlemlerde bunun örneklerine çokça rastlamaktayız. Bu konuyla ilişkili olarak Akyıldız'ın aktardığı bir vaka oldukça ilginçtir. "Tunus valisi padişaha bazı hediyeler gönderir ve bunların kabul olunduğuna dair valiye cevabî bir mektup yazılır; yazıda, hediyelerin padişahça kabul edildiğini belirtmek anlamında tevkîf kelimesi kullanılır. Vali, bunu Arapçadaki anlamıyla "alıkonuldu" ve "kabul edilmedi" şeklinde anladığı için "mahzûz ve mükesserü'l-hâtır" olur; bunun üzerine kendisine bir yazı daha gönderilerek konu açıklığa kavuşturulur. Yazıda "beyâna hâcet olmadı̆̆ı vechile her memleketin kendi muhassa nice ıstılahatı olarak bilâd-ı sâirede onların tamamıyla bilinmesi mümkün olmadığından burada kullanılan "tevkif" kelimesinin "kabul" anlamını taşıdığı"

10 Ufuk Gülsoy, “Islahat Fermanı”, İstanbul, $D \dot{I} A$, 1999, c. 19, s. 186.; Ali Akyıldı, “Tanzimat”, İstanbul, $D \dot{I} A$, 2011 , c. 40 , s. $1-10$.

11 İlber Ortaylı, "Osmanlı Arşivinde Slav Dillerindeki Dilekçelerin Bazı Örnekleri”, Osmanll-Türk Diplomatiği Seminerleri (30-31 Mayıs 1994), İstanbul: İÜ Edebiyat Fakültesi, 1995, s. 183-190.

12 İlber Ortaylı, a.g.m., s. 185.

1329 Mart 1835 tarihli bir belgede yazışmalarda 1srarla Türkçe kelimelerin kullanmasına dikkat etmemesi sebebiyle Evkaf-1 Hümayun Hazinesi Zimmet Halifesi ile Şeref Efendi’nin ceza olarak önce Bursa ve Kütahya’ya sürgün edildikleri, sürgün sebeplerinin de açı bir şekilde ifade edildiği görülmektedir. Başbakanlık Osmanlı Arşivi (BOA), Hatt-1 Hümayun Tasnifi (HAT). 513/25104. 
belirtilir ve sorun çözüme kavuşturulur ${ }^{14}$.

Bürokratik ve idari işlemlerde yerel ve yabancı dillerin kullanılması, anlam kargaşasına sebep olduğu gibi farklı dillerde hazırlanan belgeleri Türkçeye çevirmek hem meşakkatliydi hem de yanlış çevirilerden dolayı işleri aksatıyordu. Bu yüzden daha öncede zikredildiği gibi 20 Mart 1853/9 Cemaziyyelahir 1269 tarihinde yapılan bir düzenlemeyle, Osmanlı Devleti'nin yabancı devletlerin başkentlerinde bulunan sefirleriyle o tarihe kadar Fransızca olarak gerçekleştirdiği yazışmaları artık mümkün mertebe Türkçe yapması yönünde bir karar alındı ${ }^{15}$. Bu kararla sefaretlerle hükümet arasındaki bütün yazışmaların Türkçe olması değil, mümkün mertebe Türkçe yapılması kastedilmekteydi ${ }^{16}$.

Osmanlı bürokrasisinde Fransızca kullanımının yarattığı sorunlardan bir örneğe 18 Şubat 1956'da ilan edilen Islahat Fermanı ile ilgili bir konuda rastlıyoruz. Fermanın ilanından 12 gün sonra Kırım Savaşı'nın ateşkesini öngören ve bir barış antlaşması olan Paris Antlaşması 30 Mart 1956 imzalandı. Bu antlaşmada Ferman'dan da bahsedilecekti. Fakat Osmanlı Devleti, Fermanın uygulanması bu antlaşmanın bir yükümlülügüymüş gibi düşünülerek ve dolayısıyla yabancı güçlerin Osmanlı’nın iç işlerine karışma hakları varmış hissini verecek bir dilde yazılmasını istemiyordu. Bundan dolayı Antlașmaya bu Fermanı padișahın kendi isteğiyle çıkardığını belirten bir maddenin yazılması teklif edildi. Antlaşma görüşmeleri için yapılan konferansta kullanılan dil ve Antlaşmanın yazıldığı dil Fransızcaydı. Bunun için "prendre acte" ifadesi kullanıldı. Bu durum İstanbul'a telgrafla bildirildiğinde, bunun "bir garanti vermek" veya "bir anlaşma yapmak" anlamına gelebileceği düşünülerek şiddetle karşı çıkıldı. Bundan dolayı birkaç gün görüşmeler durdu. Sonunda devletlerin Islahat Fermanı'nın "yüksek değerini tanıdıkları" anlamına gelen Fransızcası "constatent la haute valeur" olan bir ifade yazıldı. Bu ifade Türkçeye "kadir-i âlisini isbat ederler" şeklinde çevrilmiştir ${ }^{17}$.

Yanlış çeviriden kaynaklanan hatalı örneklerden birine Süveyş kanalıyla ilgili bir mukavelenamede rastlıyoruz. Yıldız Saray-ı Hümâyûnu Başkitabet Dairesinden çıkan 1 Kânûn-ı evvel [1]304/13 Aralık 1888 tarihli yazıda, anlaşma incelenirken çeviriden kaynaklanan bir hata şöyle izah edilmiştir. Osmanlı Devleti ile Batılı Devletler arasında yapılan Antlaşmada -padişahın onayladığı şekliyle- hatalı tercüme olup olmadığının anlaşılması için incelenmesi emredilmiş; yapılan incelemede padişah onaylı belgenin Fransızcasında sayıları toplanan bedel harfinden başka eksik olmadığı; fakat mukavelenin Türkçe ve Fransızca nüshalarının incelenmesinde Türkçesinin ikinci maddesinde yazan "tasdik ile beraber" ifadesinin Fransızcasına uygunluğu için "tasdik ettiklerinde" yahut "tasdik ettikleri için" diye yazılması ve üçüncü maddesinde "tatlı su cetvelinin edevat, tesisat ve inşaat ve ameliyatına" ibaresine bir "dahi" eklenmesi ve on birinci maddesinin diğer fikrasındaki atıf sekizinci maddeyle

\footnotetext{
14 Akyıldız, a.g.m., s. 413.

15 BOA, Hâriciye Mektûbî Kalemi (HR. MKT.), 58/ 99.

16 Hariciyedeki yazışmalar bundan sonra tamamen Türkçe değil kısmen Türkçe olacaktı. Yani çok gerekli ise belgeler Fransızca da hazırlanabilirdi. Akyıldız, bu durumu yazısında değerlendirdiği belgenin karar metninde geçen "iktizasına göre Türkçe tahrir olunması" ifadesi ile açıklamaktadır (Ali Akyıldız, "Tanzimat Döneminde Belgelerin Şekil, Dil ve Muhteva Yönünden Geçirdiği Bazı Değişiklikler (1839-1856)", Tanzimat: Değişim Sürecinde Osmanlı İmparatorluğu, Haz. Halil İnalcık, Mehmet Seyitdanlıŏlu, İstanbul: Türkiye İş Bankası, 2006, s. 412.
}

Davison, a.g.e., s. 178 . 
bağlantısı olduğu halde üçüncü maddeye atıf verilmiş olduğu görülmüştür ${ }^{18}$.

Yabancı dille yapılan idari ișlemlerden kaynaklanan yanlış ve hatalı uygulamalar, sık yaşanmaya başladığından Bâb-ı Âlî̀yi bir takım kararlar almaya zorladı̆̆ görülmektedir. Bunun bir örneğine Maarif Nezâreti'nin bir tebliğinde rastliyoruz. Nezaretin bütün resmi daireler için çıkardığı 7 Rebî'ülevvel 1333/23 Ocak 1915 tarihli tebliğde Osmanlı Devleti’nin resmi dili Türkçe olduğu halde dairelerde hazırlanan bazı yazışma ve tezkirelerin Fransızca hazırlandığı aynı zamanda yabancı kelime ve tabirlerin sıkça kullanıldığına dikkat çekilerek, bunun yerine Türkçe ifadeler kullanılması gerektiği vurgulanmıştır. Çünkü Türkçe ibareler arasında yabancı dil genelleşerek dilin şivesi bozulmaktadır. Bu şekilde kullanılması uygun olmayan bu gibi yazı, kelime ve ifadelerin terkedilmesi, yazışmaların mümkün olduğu kadar Türkçe ibareler ile yazılması gerektiği belirtilmiştir. Aynı zamanda eskiden beri kullanılan yabancı kavramların, her daire tarafından Türkçelerini gösteren listeler hazırlanması gerektiği, bunun da her dairede bulundurularak bir sözlük gibi kullanılması lüzumu dile getirilmiştir. Böylece yabancı bir kavram kullanılması gerektiğinde onun Türkçesi bu sözlükten tespit edilip kullanılacaktır ${ }^{19}$.

\section{Memurların Yabancı Dil Bilme Meselesi ve İstihdam Problemi}

19. yüzyılın ikinci yarısından itibaren devlet idaresi ve özel şirketlerin işlemlerinde Türkçe yerine farklı yabancı dilleri kullanması; çalışanlar arasında haksız rekabete sebep olması, yabancı dil bilen Gayrimüslim memurların daha çok itibar görmesi, güvenlik ve istihbaratla alakalı risklerin ortaya çıkması, gereksiz yere Türkçe'den yabancı dillere çeviri yaptırılması sebebiyle maliyetlerin artması, yabancı dil bilgisi olmayan Türk memurların kadrolara yerleşememesi gibi problemlerin ortaya çıktığını belirten belgelere rastlanılmıştır ${ }^{20}$. Bütün bu problemlerin çözümü için merkezi hükümetin yabancı şirketlerle olan antlaşma, iş ve işlemlerinde Türkçe'nin kullanılması için 4 Zilhicce 1333/13 Ekim 1915 Harbiye ve Nafia Nezaretlerinde görevli memurlardan oluşan bir komisyon teşkil etmesi ve diğer kamu birimlerinin de ortak çalışmalarıyla hazırlanan "Mu'âmelât ve Muhâberât-ı Ticâriyenin Türkçe Kayd ve Tahrîrine Dâ'ir Kânûn Lâyihasının”, 18 Cumâde'l-ûlâ 1334/23 Mart 1916 tarihinde kanunlaştırıldığı yine yukarıda sözü geçen belge grubunda açıkça ifade edilmektedir ${ }^{21}$.

Bunu Hariciye Nezaretinde çok daha belirgin görüyoruz. Gerek Tanzimat Fermanının ardından Fransız kamu bürokrasi uygulamalarının kullanılmaya başlaması ve gerekse Hariciyedeki devlet adamlarının yabancı diller içerisinde Fransızcayı yaygın olarak bilip kullanmalarından dolayı Hariciyenin dış yazışmaları özellikle elçilik ve konsolosluklarla Fransızca yürütülmesi ${ }^{22}$ yabancı dil bilenlerin çalıştırılmasını zorunlu kılıyordu. Ne yazık ki Müslüman memur ve bürokratların yabancı dil kabiliyetleri çok sınırlıydı. Carter Findley’e göre Müslümanlar arasında yaygın olmayan bu özel dil becerisi, Gayrimüslim memurların

18 BOA, Dosya Usûlü İrâdeler Tasnifi (DUIT.), 142/39.

19 BOA, (Ma'arif Nezâreti Mektûbî Kalemi (MF. MKT.), 1207/ 3.

20 BOA, Şûrâ-yı Devlet Husûsîye (ŞD.HU.), 51/1.

21 BOA, ŞD.HU. 51/1.

22 Ortaylı, "Osmanlı Kançılaryasında Reform: Tanzimat Devri Osmanlı Diplomatikasının Bazı Yönleri”, Tarih Boyunca Paleografya ve Diplomatik Semineri (30 Nisan-02 Mayıs 1996) Bildiriler, İstanbul: İÜ, Edebiyat Fakültesi, 1988, ss153-168. , s. 163. 
Hariciye Nezaretinde kalıcı yerler edinmelerini sağlıyordu ${ }^{23}$. Dolayısıyla yabancı dil bilememek, Müslüman gençler için işe girmek noktasında dezavantaj oluşturuyordu.

Benzer durumlara farklı kurum ve ticari müesseselerde de rastlamaktayız. Gayrimüslim memurların ayrıcalıklı konuma gelmeleri ve hatta güzel eğitim almış ve mesleğinde iyi yetişmiş olmasına rağmen yabancı dil bilgileri yetersiz olduğu için Türk bürokrat ve memurların terfi alamaması ve istediği yere gelememesi farklı ticari sahalarda çok daha yaygındı. Bunlardan birini demiryolu şirketlerinde görüyoruz. Nâfia Nezaretine bağlı demiryolları başta olmak üzere diğer müesseselerde tüm idari işlemlerin Türkçe ile yapılması konusunda çıkarılan Kânûn Lâyihasının ${ }^{24}$ gerekçesinin açıklandığı tezkerede, yabancı dil bilmeyen memurların atanmasına nasıl engel olduğu açıklanmıştır. Özellikle Demiryolu şirketlerinin işlem ve yazışmalarının yabancı dilde yapılması birçok fedakarlıklara katlanılarak yetiştirilmekte olan şimendüfer asker kıtalarında yetișen personelin istihdamına mani olmuştur. Bu durumun memleketin müdafaası gibi zor günlerde sıkıntılara sebep olacağı belirtilmektedir. Bu askerlerden yeterince yararlanılabilmesi için demiryolları yazışma ve işlemlerinin Türkçe yapılmasının gerekli olduğu ifade edilmiştir ${ }^{25}$.

Türklerin bașta șirketler olmak üzere dıș ișleri ve Nafia Nezareti gibi yerlerde istihdamını güçleştiren husus yabancı dil bilgisinin yetersizliği olurken; bilenler için istihdamda öncelik söz konusuydu. Bu durum, aynı zamanda farklı ücret politikasına sebep oluyordu. Diğer bir ifadeyle, yabacı dil bilmeyen personelin istihdamı zor olurken, bilenlerin de iși beğenmeme ve daha fazla ücret alacakları işleri tercih etmeleri gibi bir durumu gündeme getiriyordu. Personelin bu yabancı dil bilgisiyle alakalı durum, resmi karar mekanizmalarında da tartışılmaktaydı. Meclis-i Vükela Müzarekatına Mahsus Zabıtname ve Meclis-i Vükelâ'nın bu konuda verdiği karar olarak karşımıza çıkan 13 Zilkade 1333/22 Eylül 1915 tarihli bir belgede, idari işlemlerde farklı dillerin yol açtığı sıkıntılar ifade edilirken bir tanesinin de yabancı dil bilen gençlerin durumuyla alakalı olduğunu görüyoruz. Özellikle yabancı dile vakıf ve yüksek tahsil görmüş gençlerin daha çok para kazanmak için demiryolu gibi şirketlerdeki işlere talip olmayıp, daha çok ücret veren yabancı firmaları tercih etmeleridir ${ }^{26}$.

İdari işlemlerin yabancı dille yapılması Gayrimüslim personelin istihdamını zorunlu kılmakta, bu durum ise güvenlik açısından riskler taşımaktaydı. Bu olumsuzluğu, başta Başkumandanlık Vekâleti olmak üzere farklı merciler gündeme getirmiștir. Başkumandanlık Vekâletinin görüșülmek üzere Meclis-i Vükelâ'ya gönderdiği 6 Zilkade 1333/15 Eylül 1915 tarihli ve 4788 sayılı tezkirede Osmanlı demiryollarında görevli olanların nerdeyse tamamının Gayrimüslim milletlerden oluşmasından dolayı bu durumun demiryollarının güvenliğini sıkıntılı bir duruma düşürdügü ifade edilmiştir. ${ }^{27}$

Devlet organlarında idari işlemleri yabancı dilde yürütmek, personel istihdamında zorluklar ve güvenlik sorunu gibi sıkıntılar doğururken, farklı maliyetlere de sebep

\footnotetext{
23 Carter V. Findley, Kalemiyeden Mülkiyeye: Osmanlı Memurlarının Toplumsal Tarihi, İstanbul: Tarih Vakfı Yurt Yayınları, 1996, s. 182.

24 BOA, ŞD.HU. 51/1.

25 BOA, ŞD.HU. 51/1.

26 BOA, Meclis-i Vükelâ (MV.), 199/18.

27 BOA, MV. 199/18.
} 
olmaktadır. Mesela bunun bir örneğini yabancı dillerden Türkçeye veya Türkçeden yabancı dillere yapılan çevirilerin maliyeti oluşturmaktaydı. 14 Şaban 1309 /13 Mart 1892 tarihli bir belgeye göre, Tıbbiye-i Mülkiye ve Sıhhiye-i Umûmiye meclislerinde yapılan görüşmelerin Türkçe olduğu, havale evrakı ve bütün işlemlerin belirlenen usûl üzere Türkçe yapıldığı, ancak bu meclislerde alınan kararların Fransızca olarak yazıldığı ve sonra Türkçe'ye tercüme edildiği ve bundan dolayı Fransızca yazışmalar için ayrıca maaşlar verildiği ifade edilmektedir. Belgede, bu uygulamanın yanlışlığı vurgulanarak, bundan sonra bu meclise havale olunan evrak ve devam eden görüşmelerin Türkçe olmasına karşın zabıtnamelerin Fransızca olarak yazılmasının uygun görülmediği açıkça ifade edilmektedir. Ayrıca bu durumun devlet usul ve kurallarına aykırılı̆̆ı sebebiyle düzeltilmesi konusunda adı geçen nezarete tebligat yapıldığı bildirilmektedir ${ }^{28}$.

Yerel dilde hazırlanan evrakın Türkçeye çevirtilmesi veya kayıtların o dilde tutturulmasıyla alakalı olarak Sadaretten zaman zaman kadro talepleri gelmiștir. Maaşlı kadroların mümkün olmadığı yerlerde ise o dilleri bilen sivil veya asker personelden yardım alınabileceği önerisi getirilmiștir. Dâhiliye Nezâreti'ne hitaben 28 Şubat 1896'da yazılan belgede, halkı çoğunlukla Hristiyan Rum olan Cezayir-i Bahr-ı Sefid Vilayetinde Rumca olan işlemler ve düzenlenen belgeler için bir memur tayin edilmesi, eğer mümkün değilse en azından halkı tamamen Hıristiyan olan köy ve mahallelerde Redif zabitlerinden istifade edilebileceği talep edilmiştir ${ }^{29}$.

\section{Kurumların Yabancı Dil Bilen Memur Talepleri}

Başta Hariciye olmak üzere Nafia ve Sıhhıye Nezâretlerinde bulunan müdürlük ve müesseselerde tamamen ya da kısmen yazışmalar ile idari işlemlerin Fransızca gibi yabancı dilde olması tabii olarak farklı yabancı dillere hâkim personel ihtiyacını doğuruyordu. Her ne kadar Gayrimüslim vatandaşlar ve yabancılar bașta olmak üzere yine yabancı dil bilen Türk memur ve bürokratlar çalıştırılsa da yeterli gelmiyordu. Bunun yanında yine devletin resmi dili Türkçe ${ }^{30}$ olmasına rağmen farklı dillerde müracaatlar yapılabiliyor; bu yüzden zaman zaman gerek merkez kurumlar ve gerekse taşra birimlerinde bu yazışmaların işlemi için personel çalıştırmakla ilgili talepler oluyordu. Bu tür taleplerin birkaçını, Gelibolu ve Bulgaristan'ın Tirnova kazasında görüyoruz.

Örneğin taşra birimlerinde yerli Gayrimüslim veya yabancllar tarafından yerel dillerde ve Fransızca gibi yabancı dillerde gelen yazışmalarla karş̧laștıkça bunların anlaşılması, işleminin yapılması ve cevabının yazılmasıyla ilgili olarak güçlükler yașanmıştır. Gelibolu Kaymakamlığına gelen farklı dillerdeki yazışmaların işlemleri için Rumca ve Fransızca yazışmalarda kullanılmak üzere bir adet yazıcının istihdamı konusunda Gelibolu Meclisinden bir talep olmuş, Meclis-i Vâlâ'ya havale edilen bu talep görüşülerek, 12 C sene 75/17 Ocak 1859 tarihli bir yazı ile verilen cevapta bu güne kadar böyle bir talebin olmadığı, bu zamana kadar olduğu gibi bundan sonra da Sancak dâhilindeki yazışmaların Türkçe olarak yapılması

28 BOA, Dâhiliye Nezâreti Mektûbî Kalemi, (DH. MKT.), 1932/72.

29 BOA, DH. MKT. 941/30.

30 Ali İhsan Gencer, “İlk Osmanlı Anayasasında Türkçe'nin Resmi Dil Olarak Kabûlü Meselesi”, Armağan: Kânûn-ı Esâsî’nin 100. Yllı, Ankara: AÜ, Siyasal Bilgiler Fakültesi, 1978, s. 187. 
gerektiği bildirilmiştir ${ }^{31}$.

Özellikle halkın farklı milletlerden oluştuğu yerlerde bu tür taleplerin daha yoğun olduğu anlaşılmaktadır. Bulgaristan'ın Tırnova kazasında 29 adet köyün 22'si Bulgarlardan meydana gelmekteydi. Bulgarcadan başka bir dil bilmeyen veya Türkçeyi kısmen bilen bu toplumun, merkezden gönderilen Türkçe emirleri anlamadıkları, aynı zamanda hükümete Bulgarca ve Rumca belge verdikleri belirtilmektedir. Bu yüzden Edirne valiliğine yazı ile bu dilleri bilen bir kâtip tayini istenmiştir. Bunun üzerine Maliye ve Dâhiliye Nezaretleriyle 6 Haziran sene [1]308/18 Haziran 1892 tarihinde yapılan yazışmalarda, devletin resmi dilinin Türkçe olduğu; bu yüzden böyle bir istihdamın mümkün olmadığı, devletle yapılan işlerde Türkçeyi kullanmaları gerektiği, Bulgarca yazışma kabul edilmeyeceği ifade edilmiştir ${ }^{32}$.

Zaman zaman bu tür tayin taleplerinin yapıldığını karşılaşılan belge örneklerinden anlıyoruz. Farklı dillerin kullanılması ve özellikle idari işlemlerde yerel diller konusu tartışmaları devam ederken 1876'da çıkarılan ve Osmanlı'da ilk anayasa olarak tarihe geçen Kânûn-ı Esâsî'de Türkçe resmi dil olarak kabul edilmiştir. Anayasa'nın 18. maddesinde Türkçe resmî dil olurken, devlette işe alınacak memur adaylarının da resmî lisan olan Türkçeyi bilmeleri şartı getirilmiştir ${ }^{33}$. Durum böyle olunca günlük dilde yaygın olarak konuşulan Türkçe, aynı zamanda kamu hizmetlerinin gerçekleştirilmesi sırasında da kullanılacaktı. Tabii olarak bu durum idari işlemlerde ve düzenlenen her türlü belgede Türkçe'nin kullanılması zorunluluğu anlamına gelmekteydi. Buna karşın özellikle Osmanlının farklı müesseseleriyle ortak iş yapan yabancı şirket ve bağlı organlar yine de Fransızca ve İngilizce gibi dillerde sözleşme hazırlayıp idari işlem yapmışlardır.

Devlet kurumları içerisinde yürütülen idari işlemler ve üretilen resmi yazışmaların Türkçe yazılması konusunda devlet adamları yanı sıra bazı sivil toplum kuruluşlarının da müdahil olmaya çalıştıkları görülür. Türk milliyetçiliğini geliştirmek, bu konuda entelektüel ve ilmi çalışmalar yapmak üzere 1908 yılında kurulan Türk Derneği de Türk dilinin sadeleşmesi için çıkarmış olduğu beyannamede bu konuyu dile getirmiștir. Beyannamenin 5. maddesi resmi yazışma dilinin halkın kolayca anlayabileceği bir duruma getirilmesi ve İmparatorluk sınırları içerisinde çeşitli dillerde yazılan ve yayınlanan ilan ve levhalarda da, matbuat nizamnamesi gereğince, anlaşılır bir Türkçenin kullanılmasını devletten istemişlerdir ${ }^{34}$.

Her ne kadar gerek Kânûn-ı Esâsî’de hem de çıkarılan kanun layihasında Türkçenin resmi dil olduğu, işlemlerde Türkçe'nin kullanılacağı belirtilse de yurt dışı münasebetlerde yabancı dil bilen memur ihtiyacının olduğu anlaşılmaktadır. Özellikle yabancılarla yürütülen ticari işler ile haberleşme faaliyetlerinde bu çalışanlara ihtiyaç olduğunu Sadrazam Hakkı Paşa'nın 1911 bütçesi görüşülürken özellikle belirttiğine şahit oluyoruz. Aynı zamanda mebusların da meşrutiyetin ilanından beri posta memurlarının niteliksizliğinin devam ettiğini, dağıtım hizmetleri eksik yürütüldüğü gibi muhabere hizmetlerinde Fransızca bilen

31 BOA, Sadâret Mektûbî Umûm Vilâyât (A. MKT. UM.) 341/20.

32 BOA, Bâb-1 Âlî Evrak Odası (BEO.), 22/ 1618.

33 Gencer, a.g.m., s. 187.

34 Yusuf Ziya Öksüz, Türkçe 'nin Sadeleşme Tarihi Genç Kalemler ve yeni Lisan Hareketi, Ankara: TDK, 1995, s. 63. 
personel olmaması nedeniyle büyük sorunların yaşandığı dile getirilmiştir³5.

Bu tartışmaların 1915'e kadar devam ettiğini mevcut yazışmalardan anlıyoruz. 17 Ekim 1915 tarihli bir tezkirenin ekinde yer alan kanun layihasında var olan ve ileride kurulabilecek şirket ve farklı kuruluşların bütün işlemlerinde ve haberleşmelerinde Türkçe kullanacakları belirtilmiştir $^{36}$. Böylece Anayasa'dan sonra tüm idari işlemlerde Türkçenin resmi dil olarak kullanılacağının en kuvvetli sesle dile getirildiğini görüyoruz.

\section{Yerel Dillerin Belgelerin Form Özelliğini Değiştirmesi}

Bürokraside yerel ve yabancı dillerin kullanılması, belgeleri içerik ve muhteva bakımından etkilediği gibi form özellikleri açısından da bir takım değişiklere sebep olmuştur. İlber Ortaylı bu yerel dillerdeki yazışmaları değerlendirirken özellikle Slav dillerinde verilen dilekçelerde Rus dilinin etkilerinin görüldüğünden bahsetmektedir ${ }^{37}$. Ortaylı Balkan milletlerinin Slav dillerinde verdikleri dilekçelerde bazı Rusça terimlerin özellikle yer aldığını belirtmektedir. 16 Nisan 1856 tarihinde Tırnova Sancağı Svişçov kasabası sakinleri kilise inşa etmek için verdikleri dilekçede elkabda yer alan Sultan Abdülmecid Han Efendimiz ifadesinden evvel Rusya imparatorları için kullanılan Gosudor İmperator deyimini Gospodár Sultan Naş tsar-i Gospodár Sultan şeklinde kullanmışlardır³. Görüldüğü gibi azınlıklar kendi dillerini yazışmalarda kullanırken, mevcut yazışma ve resmî diplomatik yazışma usulünün dışında kendi kültürlerini ifade eden deyim ve kalıpları kullanmayı tercih etmişlerdir. Yine Slav halklarının dilekçelerinde geçen bir başka özellik, isim yerine kullanılan rumuz ve kısaltmalardır. Ortaylı, yazışmalarda kullanılan isimlerin, tam vaftiz biçimiyle kaydedilmemiş olduğunu, halkın kullandığı kısaltmalar şeklinde ve Arap harfleriyle yazılmış olduğunu ifade etmektedir. Bunlara örnek olarak da belgelerde geçen Jordan isminin Danço, Ivalo'nun Valû, Stoyan yerine Stoina șeklinde yazılmasını göstermektedir ${ }^{39}$. Ortaylı makalesinde bunların bir liste halinde hazırlanmasının özellikle o bölgelere ait kayıtlarda geçen isimleri doğru tespit etmede yardımcı olacağını ayrıca vurgulamaktadır ${ }^{40}$.

Belgelerde yabancı dil kullanımıyla alakalı örneklere sadece yazıda değil mühür kullanımında da rastlamaktayız. Yabancı dildeki mühür şekilleri, şüphesiz belgelerin diplomatik hususiyetleri bakımından önemli bir niteliktir. Mesela bunun bir örneğini Rasathâne-i Âmire'de görmekteyiz. Maarif-i Umûmiye Nezâreti'nden, Rasadhâne-i Âmire'ye gönderilen 25 Şevval sene 335 /14 Ağustos 1917 tarihli bir belgeye göre, bu kurumda kullanılan mühürlerin bir kısmı Türkçe hazırlanmışken bazılarında Fransızca ibareler de bulunmaktadır. Oysa diğer resmi dairelerde kullanılan mühürlerin ibarelerinin tamamen Türkçe olması dolayısıyla bir resmi daire olan Rasathâne-i Âmire'ye ait resmî mührün Türkçe ile beraber Fransızca ibareleri içermesinin uygun olmayacağı belirtilmiş; kullanılan mührün

35 Erkan Tural, “Osmanlı Posta Bürokrasisi 1908-1914”, s. 46, c. 28, Ankara, Ankara Üniversitesi Dil ve Tarih-Coğrafya Fakültesi Tarih Bölümü Tarih Araştırmaları Dergisi, 2009, s. 222.

36 BOA, ŞD. HU. 51/1

37 Ortayli, a.g.m, s. 183-4.

38 Ortaylı, a.g.m., s. 184.

39 Ortaylı, a.g.m., s. 184-85.

40 Ortaylı, a.g.m., s. 184-85. 
hemen değiştirilmesi, bundan sonra hiç bir şekilde kullanılmaması tavsiye olunmuştur ${ }^{41}$.

\section{Azınlık Nüfusunun Yoğun Olduğu Bölgelerde Yabancı Dilin Kullanılması}

Osmanlı toprakları içerisinde bazı bölgelerin yoğun olarak Rum, Ermeni veya Arap gibi milletlerden halktan meydana geldiği bilinmektedir. Sayda Eyaleti, Cezâyir-i Bahr-i Sefid Vilayeti, Limni, Bağdat, Doğu Beyazıt, Arabistan'da yaygın olarak yerel diller konuşuluyordu. Bu durumun doğal sonucu olarak devletle olan münasebetlerini de kendi yerel dilleriyle yürütme istekleri gündeme gelmiştir. Burada Türkçe bilmeyen iki muhatap tarafla karşılaşılmaktadır. İlki, bu bölgelerde yaşayan halk, diğeri ise memur, aza ve muhtar gibi temsilci ve görevlilerdir.

Şimdiye kadar Osmanlı Arşivinden elde edilen belgeler ışığında Türkçe bilmeyen halkın idari işlemlerde karşılaştığı güçlüklerin, birkaç grupta değerlendirilebileceği görülmüştür. İlk başta dikkat çeken husus yerli halkın devletle olan işlerinde Türkçe yerine kendi bildikleri yerel dili kullanmak istemeleri. Diğer husus, devletin işlem yapmak veya bilgi sahibi olmak için gönderdiği Türkçe yazışma ve belgelerin yerli halk tarafından anlaşılamaması. Bașka bir durum ise özellikle halkın adliye veya kolluk kuvvetleri gibi zabıt, tutanak, ifade almak gibi iş ve işlemlerde bildikleri yerel dil ile ifade vermek istemeleri ve bunların kaydı ile Tercüme edilip, belgeye dönüştürülmesi meselesidir. Bunun bir örneğine 20 Ocak 1862 tarihli bir belgede rastlıyoruz. Bağdat valiliğinden cevaplanmak üzere merkeze gönderilen bir yazıda, cinayet işleyenlerden soruşturmaları gerçekleştirilen kişilerin Türkçe bilmedikleri, hatta okuyup yazma dahi bilmediklerigerekçesiyle soruşturma evraklarının yazılmasının ve imzalanmasının mümkün olmadığının bildirilmesiyle bu konuda nasıl işlem yapılması gerektiği sorulmuştur. Cevap olarak gelen yazıda soruşturmalarının kendi lisanlarıyla yazılması ve sorușturma evrakının altına imza ve mühür veya parmaklarıyla tasdik ettirildikten sonra altına Türkçe Tercümesinin yazılarak aynen gönderilmesi gerektiğinin karar verildiği belirtilmektedir ${ }^{42}$.

Türkçe bilmemek, ifade almak gibi adli işlerde zorluk yaşanmasına sebep olduğu gibi, diğer taraftan devlet ve hükümet yetkililerinin çıkardığı kanun ve talimat gibi düzenlemeleri okunup anlaşılamadığı zaman da güçlükler yaşanabilmektedir. 14 Şubat 1895 tarihli bir belgede durum şöyle izah edilmektedir. Basra Vilayeti Muhasebe Memuru İbrahim Efendi, Arabistan ve Kürdistan ahalisinin çoğu Türkçeyi bilmediklerinden yeni oluşturulan düzene ait hükümleri anlayamamaları sebebiyle birçok mahzurun ortaya çıktığını dile getirmiş; insanlarla ilgili işlemlere ait toplumsal hükümlerin Arapça ve Farsça dillerine tercüme edilerek adı geçen havalideki ahaliye yayınlanıp dağıtılması halinde birçok fayda meydana geleceğinin dile getirildiği bir rapor kaleme almıștır. Bu raporun değerlendirilerek Sadaretten Dahiliye Nezaretine gönderilen bir yazıda, kanunlar ve nizamların diğer dillere tercümesi uygun görülmediği ifade edilerek şimdilik bu öneriden vazgeçilmesi gerektiği belirtilmiştir ${ }^{43}$. Ayrıca, 2 Şubat 1895 tarihli tezkere ile gönderilen Şûrâ-yı Devlet Tanzîmat Dairesinden kaleme alınan mazbataya göre işlem yapılması emredilmiştir ${ }^{44}$.

Ahalisi yoğunlukla farklı milletlerden olan yerlerde o toplumun kendi dili 
kullanıldığından tezkere ve defter gibi bir takım resmi belgelerin de Türkçe değil, kendi dillerinde hazırlandığını görüyoruz. Bunun bir örneğine Cezâyir-i Bahr-ı Sefid Vilâyet-i Celilesi'nde rastlanmaktadır. 5 Mart sene [1]321/18 Mart 1905 tarihinde Sadarete gönderilen bir tezkereden vilayet ahalisinin çoğu Rum cemaatine mensup olduğundan vukuat, geçiş izinleri (mürur tezkireleri)'ne ait ilmühaberler Rumca olarak kullanıldığı anlașılmaktadır ${ }^{45}$. Yerel dillerde gerçekleşen bu işlem ve düzenlemeler için Rumca bilen bir katip tayini teklif edilmiş; ancak 5 Mart sene [1]321/18 Mart 1905 tarihli belgeden anlaşıldığına göre Sadaret ve Dâhiliye Vekâleti bunu uygun görmemiștir ${ }^{46}$.

Devletin dili resmiyette Türkçe olduğundan aslında yerel dil de olsa farklı dillerde yazılmış dilekçeler yetkililerce kabul edilmemekteydi. Ancak bunun mahzurlu yönleri olduğu yine o yörenin devlet görevlileri tarafından dile getirilmiştir. Türkçenin bazı bölgelerde gelişmemesinden dolayı her ne kadar ısrarla idari işlemlerin ve yazışmaların Türkçe yapılması gerektiği vurgulansa da işlerin kolaylıkla yürütülmesi için Arapça dilekçenin de kabulü teâmül/âdet hükmüne girdiğinden ve bunun şimdi hemen kaldırılmasının kötü bir tesire sebep olacağı için uygun görülmemiştir. Bundan dolayı merkezi hükümet, şimdilik Arapça arzuhallerin eskiden olduğu gibi kabul edilmesi için gerekli kişi ve makamlara tebliğde bulunulması için Bağdat valiliğine 27 Mayıs sene [1]326/9 Haziran 1910 tarihli bir emir göndermiştir ${ }^{47}$.

Yazışmalar ve belgelerin yerel dillerde yapılıyor ve yazılıyor olmasının çeşitli mahsurları dile getirilirken, konuyla ilişkili diğer bir husus da Gayrimüslimlerin yoğun olarak yaşadığı yerlerdeki muhtar, memur veya aza gibi yetkililerin Türkçe bilmemesidir. Oysa, belediye meclisi gibi yerlere seçilerek gelen üyelerin Türkçe bilmesi bir zorunluluktu ${ }^{48}$. Buna karşın Sayda Eyaleti gibi halkı Türk olmayan unsurlardan oluşan bölgelerde çalışanlar da Türkçe bilmeyen yerli halktandı. Bu şekilde olan yerlerin çoğu memur, meclis azaları ve ahalisi Türkçeye aşina olmadıklarından merkezden gönderilen genel talimatları anlamıyorlardı. Bundan dolayı talimatların gereği yerine getirilemediği gerekçesiyle Sayda Eyaleti'nden, Hükümete gönderilen 13 Rebiülevvel 1263/5 Mart 1847 tarihli arzuhalden talimatların Arapça'ya çevrilip bastırılması için izin talep edildiğini ancak merkezin cevabının bunun reddi yönünde olduğu anlaşılmaktadır ${ }^{49}$.

Rumca gibi yerel dillerle belge hazırlanırken, bunların kayıt ve işlemlerinin Türkçe yapılmasının resmi işlemlerde birçok sorunlara sebep olduğuna dair alınan şikâyet arzuhallerine cevap olarak 27 Şa'bân sene [1]313 /11 Şubat 1896 tarihli Şûrâ-yı Devlet Tanzimat Dairesi'nde çıkan karar oldukça önemlidir. Bu belgeye göre, Limni Adası köy muhtarlarının tamamının Hıristiyan olduğu, hiçbirinin Türkçe okuma-yazma bilmediklerinden eskiden beri ferağ ve intikal hakkında Rumca düzenledikleri ilmuhaberlerin liva tercümanı tarafından Türkçeye tercüme ettirildikten sonra işleme konulmakta olduğu belirtilmektedir. Bu ilmuhaberlerin iş sahipleri tarafından yazılıp resmi işlemlerin başlatılması için muhtarlara verilmesinde içeriğinin muhtar ve ihtiyar heyetleri tarafından bilinemeyeceği bu durumun ise

45 BOA, DH. MKT. 941/ 30.

46 BOA, DH. MKT. 941/30.

47 BOA, Dâhiliye Nezâreti Muharrerât-1 Umûmiye İdaresi (DH. MUI.), 103-2/ 1.

48 BOA, DH. MUI. 103-2/ 1.

49 BOA, Sadâret Mektûbî Kalemi (A. MKT.), 75/ 51. 
işlerin yürütülmesinde güçlüklere sebep olduğu vurgulanmaktadır. Ayrıca ada sakinlerinin Ziraat Bankası'na borç talebi için başvurularında, taleplerin Türkçe tercüme ettirildikten sonra işleme konulmasının uygun olacağı belirtilmesi sebebiyle bu durumdan da şikayet etmekte oldukları ifade edilmektedir ${ }^{50}$. Belge'de;

“... muktezâ-yı maslahat lede'l-müzâkere vâk'ı Limni Cezîresi ahâlîsinin ekseriyet üzre Rum lisânıyla mütekellim olarak orada evrâk-ı resmiyede lisân-ı Rumi'nin isti'mâli ba'zı teshîlâtı müstelzim olabiliyor ise de hasebü'l-hâl şu müsâ'ade hikmet-i hükumet ve siyâset nokta-i nazarından aslâ câiz olmayıp çünkü cezîreye mahsûs gösterilecek mezkûr müsâ'ade sû-i sirâyeti îcâb ederek meselâ Arabistandaki muhtarlar yalnız Arapça bildiklerinden verecekleri ilmuhaberleri dahi Arapça vermeyi ve Yanya Vilâyetiyle Cezâyir-i Bahr-ı Sefîd'in sâir yerlerinde Rumca olarak tanzîmini ve Anadolu'nun ba'zl yerlerindeki Ermeni muhtarları da Ermenice yazmağa ve Bulgar ve ulah vilayet ve Arnavud milletleri muhtârânı dahi kendi lisânlarının isti'mâlini taleb ve iddi'â edecekleri cihetle bu sûret-i teşennüt mu'âmelâtı dâ'î ve envâ'-l mehâzirin tevellüdü tabî'i..."

denilerek bu tür uygulamaların ülkenin diğer taraflarında da yaygınlaşabileceğinden korkulduğu anlaşılmaktadır. Belgenin devamında öncelikle devletin resmi dilini bilmek halkın her ferdine ve özellikle devlet işlemleri ile az çok uğraşan muhtarlar için de geçerli olduğu vurgulanıp, devletin resmi dilinin öğrenilmesi özel bir kanuna bağlanıp bu konuda kolaylık dahi gösterildiğinden, önceden olduğu gibi evrakların resmî dille yazılması gerekliliği kesin bir ifade ile emredilmektedir. Belgede Rumca olarak düzenlenen ferağ vesair ilmuhaberlerinin liva tercümanı tarafından parasız olarak tercüme edilip, aslına uygunluğu tasdik olunduktan sonra kullanıma konulmasının uygun olacağı kararlaştırıldığı da belirtilmektedir. Bu belge ile Rumca'nın dışında Arapça, Ermenice, Bulgarca ve Arnavutça gibi diğer yerel mahalli dillerle yapılacak resmi yazışmaların da önü alınmış görülmektedir ${ }^{51}$.

\section{SONUÇ}

Osmanlı Devletinde 1839 yılında yayınlanan Tanzimat Fermanının ardından, özellikle idari işlemler sırasında üretilen her hangi bir sözleşmeden, sıradan bir arzuhal veya istidaya kadar çoğu belgede, Türkçe'nin yanı sıra yabancı dillerin de kullanılması talepleri gündeme gelmiştir. Bazı vilayet, liva ve köylerde yerel halkın dilinde Rumca ve Arapça belge üretilmiş, bununla ișlem yapılmak istenmiştir. Bu tür uygulamalar bir takım problemi de beraberinde getirmiştir.

Makalede Osmanlı Bürokrasisinde yaşanan dil problemleri beş başlık altında ele alınmıştır. Yabancı dillerle yapılan bürokratik işlemlerde ilk yaşanan sıkıntı yazışmalarda karşılaşılan anlam karmaşasıdır. Bu karmaşanın ortadan kaldırılması için yabancı dillerde yazışma yapılmasının yasaklanması ve yabancı tabirlere karşılık gelen Türkçe kelime ve ifadelerin kullanılması için cetveller hazırlanması bir çözüm olarak görülmüştür. Rastlanan ikinci problem Osmanlı bürokrasisi içerisinde yer alan memurların yabancı dile aşina olmamaları sebebiyle dil bilenlerin istihdamda öne geçmesidir. Personelin yabancı dil bilmemesiyleilgili bu tür bir problem ortaya çıkarken, bilenlerin de düşükücretli memuriyetlere

$\begin{array}{ll}50 & \text { BOA, A. MKT. 75/ } 51 . \\ 51 & \text { BOA, BEO. } 746 / 55906 .\end{array}$ 
ilgi göstermedikleri görülmüştür. Bu konuda en büyük sıkıntı Hariciye Nezareti ile Nafia Nezaretinde rastlanmaktadır. Bu sorunun çözümü için de yazışmaların devletin resmî dili olan Türkçe ile yapılmasıyla çözüleceği belirtilmiştir. Bu konuda üçüncü sorun, kurumların yabancı dil bilen memur taleplerinin artmasıdır. Buna karşılık olarak çalışmada, özellikle Rum, Arap, Bulgur vs. gibi halkın, yoğun olarak yaşadığı yerlerdeki bürokratik işlemler için bu dilleri bilen memurların tayin edilmesine yönelik taleplerin merkez tarafından geri çevrildiği görülmüştür.

Bürokraside yerel dillerin kullanılmasıyla ortaya çıkan belgelerde öncekilere göre bir takım farklılıklar tespit edilmiştir. Bunlar isimlerin kısaltma olarak yazılması, elkap gibi kalıp ve ifadelerin Türkçe yazışmalarda kullanılan şekliyle değil de o dilin ait olduğu milletin kültür hususiyetlerine göre şekil alması bu makalede göze çarpan hususlar olmuştur.

Araştırma sırasında Tanzimat sonrası Osmanlı bürokrasisinde Rumca bir arza, Fransızca bir sözleşmeye rastlanmıştır. Fakat, resmi prosedür ve teamüllerin dışına çıkmak demek olan bu uygulamalar kabul görmemiștir. Azınlık nüfusunun yoğun olduğu bölgelerde Arapça, Bulgarca, Yunanca gibi dillerin yazıșma dili olarak kullanılma taleplerinin olduğu tespit edilmiş; devlet ise bu tür talepleri reddetme yönünde kararlar almıştır. Sonuçta bu farklı dilleri kullanmak yerine devletin tamamen yazışma dilinde Türkçe'ye dönüldüğü görülmektedir. Varılan sonuçların, Tanzimat sonrası Osmanlı bürokrasisini inceleyen araştırmalara katkı yapacağı umulmaktadır.

\section{Teşekkür:}

Bu makalenin hazırlanması sırasında özel arşivini kullanmamıza müsaade eden Prof. Dr. Bilgin Aydın'a teşekkür ederiz.

\section{KAYNAKÇA}

\section{Arşiv Belgeleri}

Başbakanlık Osmanlı Arşivi, (BOA.)

Sadâret Mektûbî Kalemi (A. MKT.), 75/51.

Sadâret Mektûbî Kalemi Umûm (A. MKT. UM.), 341/20; 534/39.

Bâb-ı Âli Evrak Odası Evrakı (BEO.), 22/1618.; 746/55906.

Dosya Usûlü İradeler Tasnifi (DUİT.), 142/39.

Dâhiliye Mektûbî Kalemi (DH. MKT.), 348/65.; 941/30.; 1932/72. 
Dahiliye Nezâreti Muharrerât-ı Umûmiye Dairesi (DH. MUİ.), 103-2/1.

Hatt-ı Hümâyûn Tasnifi (HAT.), 513/25104.

Hâriciye Mektûbî (HR. MKT.), 58/99.

Ma'arif Nezâreti Mektûbî Kalemi (MF. MKT.), 1218/40.; 1207/3.

Meclis-i Vükelâ (MV.), 199/18.

Şûrâ-yı Devlet Husûsiye (ŞD. HU.), 51/1.

\section{Tetkik Eserler}

Akyıldı, Ali, “Tanzimat Döneminde Belgelerin Şekil, Dil ve Muhteva Yönünden Geçirdiği Bazı Değişiklikler (1839-1856)", Tanzimat: Değişim Sürecinde Osmanlı Imparatorluğu, Haz. Halil İnalcık, Mehmet Seyitdanlığlu, İstanbul: Türkiye İş Bankası, 2006, ss. 405-418.

Akyıldız, Ali, “Tanzimat”, c. 40, İstanbul, DİA, 2011, s. 1-10.

Aydın, Bilgin, “Osmanlı Bürokrasisinde Doğu-Batı Dilleri ve Türkçe”, Essays in Memory of Hazel E. Heughan, Ed. İsmail E. Erünsal, Chistopher Ferrard, Hamza Kandur, A. Oğuz İcimsoy, Niyazi Çiçek, Edinburg: Hazel E. Heughan Educational Trust Publication, 2007. s. 49-58.

Balcı, Sezai. “Osmanlı Devleti'nde Modernleşme Girişimlerine Bir Örnek: Lisan Mektebi”, Ankara Üniversitesi Dil ve Tarih-Coğrafya Fakültesi Tarih Bölümü Tarih Araştırmaları Dergisi, c. 27, s.44, 2008, s.77-78.

Davison, Roderic H. “Ondokuzuncu Yüzyıl Osmanlı Reformlarına Araç Olarak Fransız Dili”, Çev. Çiğdem Erkal İpek, Dokuz Eylül Üniversitesi Atatürk İlkeleri ve İnkılap Tarihi Enstitüsü Çağdaş Türkiye Tarihi Araştırmaları, c.2, s.4-5, 1995, ss.171-188.

Delilbaşı, Melek, Türk Hükümdarlarına Ait Yunanca Ahidnameler ve Nameler (XIII-XV. Yüzyıl), Ankara Üniversitesi DTÇF Ortaçağ Tarihi Kürsüsü, 1980 (Yayınlanmamış Doçentlik Tezi), ss. 11-40.

Findley, Carter V., Kalemiyeden Mülkiyeye: Osmanlı Memurlarının Toplumsal Tarihi, İstanbul: Tarih Vakfi Yurt Yayınları, 1996, s. 182.

Gülsoy, Ufuk, “Islahat Fermanı”, c. 19, İstanbul, DİA, 1999, s. 186.

Gencer, Ali İhsan “İlk Osmanlı Anayasasında Türkçe'nin Resmi Dil Olarak Kabûlü Meselesi”, Armağan: Kânûn-ı Esâsî’nin 100. Yılı, Ankara: AÜ, Siyasal Bilgiler Fakültesi, 1978, 183-189, s. 187.

Gümüş, Hüseyin, Hüseyin Gümüş, "Fransızca ve Francophonıe: Niçin, Ne Zaman, Nerede, Nasıl ?", Türkish Studies International Periodical For the Languages Literature and History of 
Turkish or Turkic, vol. 8/10 Fall 2013, s. 295-311.

Lewis, Bernard H., Müslümanların Avrupa'yı Keşfi, Çev. Dr. Nimet Yıldırım, Erzurum: Birey, 1997.

Ortaylı, İlber, “Osmanlı Arşivinde Slav Dillerindeki Dilekçelerin Bazı Örnekleri”, OsmanlıTürk Diplomatiği Seminerleri (30-31 Mayıs 1994), İstanbul: IUÜ Edebiyat Fakültesi, 1995.

Ortaylı,İlber, "OsmanlıKançılaryasındaReform:TanzimatDevriOsmanlıDiplomatikasının Bazı Yönleri”, Tarih Boyunca Paleografya ve Diplomatik Semineri (30 Nisan-02 Mayıs 1996) Bildiriler, İstanbul: İÜ, Edebiyat Fakültesi, 1988, ss153-168.

Öksüz, Yusuf Ziya, Türkçe'nin Sadeleşme Tarihi Genç Kalemler ve yeni Lisan Hareketi, Ankara: TDK, 1995, s. 63.

Tural, Erkan, "Osmanlı Posta Bürokrasisi 1908-1914”, s. 46, c. 28, Ankara, Ankara Üniversitesi Dil ve Tarih-Coğrafya Fakültesi Tarih Bölümü Tarih Araştırmaları Dergisi, 2009, ss.205-230. 